\title{
Hypoxia effects on oxidative stress and immunocompetence biomarkers in the mussel Perna perna (Mytilidae, Bivalvia)
}

\author{
Lílian Nogueira $^{\text {a, } 1}$, Danielle Ferraz Mello b, ${ }^{\text {, }}$, Rafael Trevisan ${ }^{\text {b, } 1}$, Danielly Garcia ${ }^{\text {a }}$, \\ Daiane da Silva Acosta ${ }^{\mathrm{b}}$, Alcir Luiz Dafre ${ }^{\mathrm{b}}$, Eduardo Alves de Almeida ${ }^{\mathrm{a}, \mathrm{c}^{,} \text {* }}$ \\ a Laboratório de Biomarcadores de Contaminação Aquática, Departamento de Quimica e Ciências Ambientais, Universidade Estadual Paulista (IBILCE/ \\ UNESP), 15054-000, São Jose do Rio Preto, SP, Brazil \\ ${ }^{\mathrm{b}}$ Laboratório de Defesas Celulares, Departamento de Bioquimica, Universidade Federal de Santa Catarina, 88040-900, Florianopolis, SC, Brazil \\ c Departamento de Ciências Naturais, Fundação Universidade Regional de Blumenau (FURB), 89030-903, Blumenau, SC, Brazil
}

\section{A R T I C L E I N F O}

\section{Article history:}

Received 3 November 2016

Received in revised form

21 February 2017

Accepted 22 February 2017

Available online 24 February 2017

\section{Keywords:}

Reduced oxygen levels

Bivalves

Antioxidant defenses

Hemocytes

Immune system

\begin{abstract}
A B S T R A C T
This study investigated the effects of hypoxia on oxidative stress response and immune function in mussels Perna perna exposed to air for 6, 12, 24 and 48 h. In air-exposed mussels, the antioxidant enzymes superoxide dismutase (SOD), catalase, and glutathione reductase (GR) activities were lower in gill tissues $(24-48 \mathrm{~h})$ and digestive gland $(12 \mathrm{~h})$, while the glutathione peroxidase and GR activities were increased in the digestive gland $(48 \mathrm{~h})$. In both tissues, aerial exposure promoted a rapid (6 h) and persistent (up to $48 \mathrm{~h}$ ) increase of glutathione levels. Decreased hemocyte count and viability, as well as increased phagocytic activity and cellular adhesion capacity were detected after prolonged aerial exposure $(>12 \mathrm{~h})$. In summary, induction of thiol pools, altered antioxidant enzyme activities, and activation of immune responses were detected in hypoxia exposed brown mussels, indicating hypoxia induced tissue-specific responses in both antioxidant and immune systems.
\end{abstract}

(C) 2017 Elsevier Ltd. All rights reserved.

\section{Introduction}

The brown mussel Perna perna is a bivalve species distributed in tropical and subtropical regions of the Atlantic and Indian Oceans: from the Caribbean Sea to the southern coast of South America, and along both coastlines of the African continent (Siddall, 1980). It colonizes hard substrata (natural or man-made) in the intertidal and shallow subtidal zones (Berry and Schleyer, 1983), where it is exposed to environmental stressors such as fluctuation in oxygen, temperature and salinity, and discharge of environmental pollutants. Although it is expected that organisms living in the intertidal zones are well adapted to the recurring stress of anoxia, hypoxia and hyperoxia during the low tide periods (Abele et al., 2007; Zardi et al., 2015), with the recent and alarming emergence of dead zones (areas in oceans or lakes with depleted oxygen levels due to pollution, warmer temperatures and eutrophication), hypoxic conditions can occur beyond their capacity of adaptation. Indeed,

\footnotetext{
* Corresponding author. Departamento de Ciências Naturais, Fundação Universidade Regional de Blumenau (FURB), Rua Antônio da Veiga 140, 89030-903, Blumenau, SC, Brazil.

1 These authors contributed equally.
}

these dead zones have been considered a significant threat to the aquatic life worldwide (Diaz and Rosenberg, 2008). Therefore, carefully addressing the toxicity of prolonged hypoxic conditions in aquatic species may help to characterize possible adverse outcomes to natural populations.

The tolerance to low oxygen levels can be different among the taxa, but is usually associated with decreased protein synthesis, suppression of Krebs cycle enzymes and lower adenosine triphosphate (ATP) production rate (Hermes-Lima and Zenteno-Savi;n, 2002). As consequence, hypoxia may cause reduced food intake and larval and adult growth rates (Welker et al., 2013). Remarkably, despite low oxygen levels and ATP turnover rates, increased production of mitochondrial reactive oxygen species (ROS) is a common response to hypoxia (Chandel et al., 2000). Previous research (Chandel et al., 2000) propose that under hypoxic conditions, ROS can act as signaling molecules in intracellular pathways at low to moderate levels (D'Autréaux and Toledano, 2007), and modulate the cellular function associated with the activity of kinases, phosphatases and transcription factors (Murphy, 2009). On the other hand, ROS can also oxidize biomolecules such as deoxyribonucleic acid (DNA), proteins, and lipids. Additionally, excessive ROS production may favor development of pathological conditions 
(Schrader and Fahimi, 2006), via accumulation of oxidative damage in various cellular compartments (Nordberg and Arnér, 2001), and dysregulation of redox-sensitive metabolic and signaling pathways. Consequently, hypoxic conditions are commonly associated with increased cellular damage (Hermes-Lima et al., 2015) and loss of cellular function.

In bivalves, short-term hypoxia and anoxia are known to rapidly decrease mitochondrial respiration (Sussarellu et al., 2013), increase hypoxia-inducible factor expression (Giannetto et al., 2015), and can result in overexpression of antioxidant enzymes and mitochondrial respiratory chain subunits (Sussarellu et al., 2010). After hypoxia/anoxia, reestablishment of oxygen levels usually leads to a burst of ROS production and oxidative stress (Garbarino et al., 2015; Hermes-Lima et al., 2015). Many studies demonstrated an increase in antioxidant defenses induced by short-term hypoxia in marine invertebrates such as polychaetes (Abele et al., 1998), gastropods (Ferreira et al., 2003), and bivalves including oysters (David et al., 2005) and mussels (Almeida et al., 2005). It is accepted that this pre-activation of the antioxidant system at early hypoxia is an adaptation or an anticipatory response to reoxygenation, preventing the accumulation of oxidative damage (Gorr et al., 2010; Hermes-Lima et al., 2015; Moreira et al., 2016).

It is also known that hypoxia can negatively affect the immune system of bivalves, once oxygen is essential for the hemocyte respiratory burst that occurs during phagocytosis (Fisher et al., 1987; Pampanin et al., 2002; Cheng et al., 2004a, 2004b; Monari et al., 2007; Wang et al., 2011). This condition could turn animals more susceptible for pathogen infections, since hypoxia can increase hemocyte mortality, affect the phagocytosis, cellular adhesion and ROS production rate, and impair the lysosomal membrane integrity. These effects were previously observed in mussels Perna viridis (Wang et al., 2012, 2014), mussels Mytilus coruscus (Sui et al., 2016) and clams Chamelea gallina (Pampanin et al., 2002). This modulation of the immune system can be a serious threat to bivalves living in areas with hypoxic conditions and high abundance of microorganisms, for instance in eutrophic areas receiving urban effluents (Johnson et al., 2007).

Considering that (i) marine organisms need an efficient antioxidant system to cope with excessive ROS formed during hypoxia/ reoxygenation, (ii) the immune system is compromised during such events, (iii) increased hypoxic events are an emerging environmental concern, the aim of this work was to examine effects of prolonged air exposure on antioxidant defenses and immune competence in brown mussels $P$. perna (Mytilidae, Bivalvia). Brown mussels were chosen since they are a bivalve species widely distributed in the southern hemisphere, inhabiting areas highly subjected to environmental pollution and hypoxic conditions.

\section{Methods}

\subsection{Organisms and chemicals}

Brown mussels Perna perna (Bivalvia, Mytilidae) both male and female $(6-9 \mathrm{~cm})$ were obtained from a mussel farm in Florianópolis, Santa Catarina, Brazil. In the laboratory, mussels were kept in tanks for five days before the experiments. Each tank was filled with $1 \mathrm{~L}$ of filtered seawater (FSW) per animal, which was under constant aeration, temperature $\left(\sim 15^{\circ} \mathrm{C}\right)$, salinity ( $\left.35 \mathrm{psu}\right)$ and $\mathrm{pH}$ $(\sim 7.7)$. The seawater was changed daily, and a commercial plankton-based food (Sera Coraliquid) was added to the water column every two days.

All reagents used in the biochemical analyses and immunocompetence assays were purchased from Sigma Chemical (St. Louis, MO, USA).

\subsection{Experimental procedures}

Sixty-four mussels were equally distributed to eight groups. Control groups were kept for 6 h, 12 h, 24 h and 48 h in tanks with seawater (same conditions of the acclimation period). Hypoxia was induced by aerial exposure for $6,12,24$ or 48 h by removing water from experimental tanks (Air exposure). When mussels are out of water, they close their shells, keeping a reserve of water inside. Under this condition, there is little supply of oxygen to their gills, leading to a hypoxic state.

This condition is close to what happens in the natural environment during low tides, so the water inside the shells was not removed. At indicated time points the gills and digestive glands were removed and stored at $-80^{\circ} \mathrm{C}$.

To evaluate immunocompetence using hemocytes, all assays must be carried out with fresh and non-stressed mussels and hemocytes. Considering the time required for hemolymph collection, quality assessment and preparation, an experimental design with fewer animals and groups were chosen. For this purpose thirty-five mussels were equally distributed in five groups. One control group was kept in tanks with seawater (same conditions of the acclimatization period) and the other four groups were kept for $6 \mathrm{~h}, 12 \mathrm{~h}$, $24 \mathrm{~h}$ and $48 \mathrm{~h}$ in tanks without water, in the same conditions as detailed above. All exposures were carried out to finish at the same time (with 10-15 min interval for each group), that is, the air exposure periods were adjusted to finish at the same time for all groups, and the control group was also collected at this time. Therefore, only one control group was chosen for the immune competence assays. At the end of exposures, the hemolymph was collected with a cold $1 \mathrm{ml}$ syringe coupled to a $0.8 \times 30 \mathrm{~mm}$ needle and samples were analyzed by light microscopy for the presence of gametes, microorganisms and cell aggregates.

\subsection{Biochemical analyses}

\subsubsection{Enzyme activities and protein quantification}

To assess enzymes activity and protein amount, first the tissues were homogenized (1:4, vol: vol) in $20 \mathrm{mM}$ Tris buffer, $\mathrm{pH} 7.4$, containing $0.5 \mathrm{mM}$ sucrose, $0.15 \mathrm{mM} \mathrm{KCl}$ and protease inhibitor ( $1 \mathrm{mM}$ PMSF), and centrifuged at $10,000 \mathrm{x}$ g for $20 \mathrm{~min}$ at $3{ }^{\circ} \mathrm{C}$. Then, supernatant was collected and centrifuged for one hour at $50,000 \mathrm{x} \mathrm{g}$ and $3{ }^{\circ} \mathrm{C}$. The supernatant was stored at $-80^{\circ} \mathrm{C}$ prior to further analyses in a Victor X3 plate reader (PerkinElmer). Glutathione S-transferase (GST) activity was measured at $340 \mathrm{~nm}$ following Keen et al. (1976). Glutathione reductase (GR) was assessed according to Carlberg and Mannervik (1985) at $340 \mathrm{~nm}$. Superoxide dismutase (SOD) was evaluated at $550 \mathrm{~nm}$ according to method developed by McCord and Fridovich (1969). Catalase (CAT) activity was quantified at $240 \mathrm{~nm}$ by Beutler's method (1975). Glutathione peroxidase (GPX) activity was analyzed at $340 \mathrm{~nm}$ as described by Sies et al. (1979). Protein levels were measured at $595 \mathrm{~nm}$ by the method of Bradford (1976) using bovine serum albumin as standard.

\subsubsection{Reduced glutathione (GSH)}

Gills and digestive glands were homogenized in $500 \mathrm{mM}$ perchloric acid (1:10, weight: volume) and centrifuged for ten minutes at $5000 \mathrm{x} \mathrm{g}$ at $4{ }^{\circ} \mathrm{C}$. Next, the supernatant fraction was collected. The GSH (reduced, not total) concentration was determined by High Performance Liquid Chromatography (HPLC). The system has an ESA584 pump and it was coupled to a coulometric electrochemical detector (ESA Coulochem III, Bedford, MA) associated to an electrochemical pre-conditioning cell maintained at a potential of $+900 \mathrm{mV}$ for mobile phase oxidation, and a dual analytical cell set at $300 \mathrm{mV}$ (first cell), and at $650 \mathrm{mV}$ (second cell) 
for GSH detection. The samples were separated in an ACE 5 C-18 column $(250 \times 4.6 \mathrm{~mm}, 5 \mu \mathrm{m})$ at an isocratic flow of $0.9 \mathrm{~mL} \mathrm{~min}{ }^{-1}$ using potassium phosphate $0.05 \mathrm{~mol} \mathrm{~L}^{-1}, \mathrm{pH} 7.0$, with $40 \%$ methanol as mobile phase. GSH peak identification and quantification was performed using software EZ Chrom (Agilent Technologies). The GSH concentration was quantified based on a standard curve previously injected with known concentrations of GSH (RodriguezAriza et al., 1994).

\subsubsection{Lipid peroxidation}

Tissues were homogenized in $100 \mathrm{mM}$ Tris buffer, pH $8.0(1: 3$ weight: vol). After this step, $0.3 \mathrm{~mL}$ of $0.4 \%$ thiobarbituric acid (TBA) in $200 \mathrm{mM} \mathrm{HCl}$ were added to each sample. Then, samples were incubated at $90{ }^{\circ} \mathrm{C}$ for $40 \mathrm{~min}$. After this period, $1 \mathrm{~mL}$ of n-butanol was added and then the samples were centrifuged at 3,500 rpm for three minutes. The supernatant fraction was collected and $20 \mu \mathrm{L}$ of each sample was used for the analysis. The malondialdehyde (MDA) concentration was determined by HPLC coupled to an UV/Vis detector set at $532 \mathrm{~nm}$. The HPLC system (ESA) consisted of ESA584 pump and an ESA526 UV/Vis detector. The column used was an ACE $5 \mathrm{C} 18(250 \times 4.6 \mathrm{~mm}, 5 \mu \mathrm{m})$. Chromatogram monitoring and peak identification and quantification were performed using the EZ Chrom Elite software (Agilent Technologies). The mobile phase was $0.05 \mathrm{M} \mathrm{KH}_{2} \mathrm{PO}_{4}$, pH 7.0, with $40 \%$ methanol, and was pumped at an

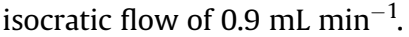

\subsection{Immune competence assays}

All assays were carried out according to previous protocol (Mello et al., 2015), with minor modifications as follows.

\subsubsection{Total hemocyte count}

After collection, samples were immediately diluted 5 times in $\mathrm{NaCl}$-adjusted phosphate buffer saline (PBS, $513 \mathrm{mM} \mathrm{NaCl}, 2.7 \mathrm{mM}$ $\left.\mathrm{KCl}, 10 \mathrm{mM} \mathrm{Na}_{2} \mathrm{HPO}_{4}, 2 \mathrm{mM} \mathrm{KH} \mathrm{PO}_{4}, \mathrm{pH} 7,4\right)$ and analyzed in a TC20 Automated Cell Counter (Bio-Rad).

\subsubsection{Cellular viability assays}

The cellular viability was investigated by two different assays: the 3-(4,5-dimethylthiazol-2-yl)-2,5-diphenyltetrazolium bromide (MTT) and the neutral red retention assay (NRR). For the MTT assay, $1 \times 10^{6}$ cells were incubated in $300 \mu \mathrm{L}$ of $0.5 \mathrm{mg} \mathrm{L}^{-1}$ MTT in PBS for $1 \mathrm{~h}$ in the dark, centrifuged ( $800 \mathrm{x} \mathrm{g}$ for $10 \mathrm{~min}$ at $4{ }^{\circ} \mathrm{C}$ ) and dyeextracted with $200 \mu \mathrm{l}$ of dimethyl sulfoxide. For the NRR assay, $3 \times 10^{5}$ cells were incubated in $300 \mu \mathrm{L}$ of $0.004 \%$ neutral red in PBS, incubated for $3 \mathrm{~h}$ in the dark. Thereafter samples were centrifuged ( $800 \mathrm{x}$ g for $10 \mathrm{~min}$ at $4{ }^{\circ} \mathrm{C}$ ) and washed three times with PBS and dye-extracted with $200 \mu \mathrm{L}$ of acidified ethanol (50\% ethanol/1\% acetic acid). Absorbance was recorded in 96 wells plates at $550 \mathrm{~nm}$ (MTT) or $560 \mathrm{~nm}$ (NRR). The control group was used as $100 \%$ viability.

\subsubsection{Phagocytic activity}

To determine the percentage of hemocytes able to phagocyte latex microsphere, $2 \times 10^{5}$ cells were suspended in $0.22 \mu \mathrm{m}$ filtered seawater. Cells were added to cytometer tubes containing equal volume of filtered sterile plasma (from a pool of fresh hemolymph from P. perna) and 0.05\% latex microspheres (Fluoresbrite, YG Microspheres, $2 \mu \mathrm{m}$, Polysciences) in order to promote microsphere opsonization, which facilitates phagocytosis. After $30 \mathrm{~min}$ on ice, cells were incubated at $20^{\circ} \mathrm{C}$ in the dark for $1 \mathrm{~h}$, and the percentage of hemocytes able to engulf 3 or more microspheres was assayed by flow cytometry (Flow Cytometer FACSCanto II, BD Biosciences) using FIT-C channel. All samples were assayed in duplicate. Data analyses were carried out with Flowing Software Version 2.5.1.

\subsubsection{Cellular adhesion capacity}

Hemocyte adhesive capacity was analyzed with $5 \times 10^{5}$ cells suspended in FSW and added to flat-bottom 96-well plates. Samples were left to adhere to the plate for $45 \mathrm{~min}$ at $20^{\circ} \mathrm{C}$ in the dark, and after the supernatant removal, FSW containing $4 \%$ formaldehyde was added and plates were maintained at $4-8{ }^{\circ} \mathrm{C}$ until use. Cells that remained in the supernatant (non-adhered) were counted using a TC-20 Automated Cell Counter (Bio-Rad). The percentage of adhered cells was based on the amount of non-adhered cells and the number of cells used in the assay. All samples were analyzed in duplicates.

\subsection{Statistical analyses}

Normality and homogeneity of the data were verified using respectively Shapiro-Wilk and Levene tests. Regarding the biochemical assays, for parametric data, Control group and airexposed group from the same experimental time were compared using student $t$-test. In case of non-parametric data, Mann-Whitney test was used instead. For the immunocompetence assays, data were analyzed by Kruskal-Wallis test followed by Dunns Multiple Comparison Test. Data were expressed as average \pm standard deviation. Data were considered statistically different from control group when $\mathrm{p}<0.05$.

\section{Results}

In the gills, SOD activity decreased after $24 \mathrm{~h}$ and $48 \mathrm{~h}$ of air exposure (Table 1). CAT activity was also reduced after $24 \mathrm{~h}$ (Table 1). In the digestive gland, SOD and GR activities were decreased after $12 \mathrm{~h}$ of exposure to air, while GPx and GR activities were increased at $48 \mathrm{~h}$ (Table 2).

Compared to the control, air-exposed mussel gills showed higher concentrations of GSH across several exposure periods (6, 24 and $48 \mathrm{~h}$ ) (Fig. 1). The same pattern of increased GSH levels was observed in the digestive gland after 6,12 and $48 \mathrm{~h}$ of air exposure (Fig. 1). MDA levels remained unaltered after aerial exposure in gills (Table 1), and digestive gland (Table 2) tissues.

After aerial exposure for 24 or $48 \mathrm{~h}$, some of the immune parameters were altered in brown mussels. The number of circulating hemocytes decreased $73 \%$ after $48 \mathrm{~h}$ of aerial exposure (Fig. 2A). The MTT assay did not detect any changes in hemocyte viability (Fig. 2B). However after 24 and 48 h hemocytes presented a $\sim 50 \%$ decrease in the neutral red retention (Fig. 2C). Hemocytes of mussels exposed to the air also showed higher immune-related activities, such as $50-60 \%$ increase in the phagocytic activity after 12 to $48 \mathrm{~h}$ (Fig. 2D), and a higher cellular adhesion capacity, increasing from $95 \%$ in the control group to $97-99 \%$ in animals exposed to the air for 12 to $48 \mathrm{~h}$ (Fig. 2E).

\section{Discussion}

In the present study, mussels exposed to prolonged hypoxia $(>12 \mathrm{~h}$ ) presented lower activity of antioxidant enzymes in the gills (SOD and CAT) and digestive gland (SOD). Although it is known that hypoxia is associated with a burst in ROS, Welker et al. (2013) and Hermes-Lima et al. (2015) suggested that such ROS generation occurs within the first hours of the $\mathrm{O}_{2}$ depletion, and the remaining $\mathrm{O}_{2}$ continues to be partially reduced by complex II and III. On the other hand, Rivera-Ingraham et al. (2013) demonstrated that prolonged hypoxic conditions (48-72 h) are associated with lower ROS production in the gills of mussels Mytilus edulis, possibly explaining the lower SOD and CAT activities detected in our study. Such pattern of decrease in antioxidant enzymes by prolonged hypoxia/ anoxia has been indicated, for instance, by lower SOD and CAT 
Table 1

Enzymes activities and peroxidation levels in gills of Perna perna mussel kept in clean seawater (Control) and after aerial exposure (Aerial) for 6 h, 12 h, 24 h and 48 h.

\begin{tabular}{|c|c|c|c|c|c|c|c|}
\hline Time & Group & SOD $^{*}$ & CAT $^{*}$ & $\mathrm{GPx}^{* *}$ & $\mathrm{GR}^{* *}$ & $\mathrm{GST}^{* *}$ & $\mathrm{MDA}^{* * *}$ \\
\hline \multirow[t]{2}{*}{$6 \mathrm{~h}$} & Control & $283.3 \pm 237.1$ & $4.4 \pm 1.7$ & $13.7 \pm 6.9$ & $133.9 \pm 69.3$ & $1269.9 \pm 788.7$ & $3.5 \pm 0.4$ \\
\hline & Aerial & $201.3 \pm 68.9$ & $4.0 \pm 1.0$ & $11.6 \pm 4.7$ & $124.9 \pm 66.9$ & $749.9 \pm 185.5$ & $3.4 \pm 0.5$ \\
\hline \multirow[t]{2}{*}{$12 \mathrm{~h}$} & Control & $46.7 \pm 16.9$ & $4.9 \pm 1.7$ & $4.0 \pm 2.6$ & $105.8 \pm 22.5$ & $733.3 \pm 289.8$ & $3.2 \pm 0.8$ \\
\hline & Aerial & $41.2 \pm 9.2$ & $3.8 \pm 1.6$ & $5.7 \pm 2.9$ & $102.4 \pm 32.2$ & $901.4 \pm 212.4$ & $3.1 \pm 0.4$ \\
\hline \multirow[t]{2}{*}{$24 \mathrm{~h}$} & Control & $70.5 \pm 21.2$ & $7.5 \pm 2.3$ & $2.9 \pm 3.6$ & $150.6 \pm 58.9$ & $1117.5 \pm 248.8$ & $1.7 \pm 0.3$ \\
\hline & Aerial & $52.3 \pm 7.0^{\mathrm{a}}$ & $4.9 \pm 1.6^{a}$ & $4.1 \pm 2.4$ & $120.4 \pm 20.7$ & $1,1174.1 \pm 333.1$ & $1.8 \pm 0.4$ \\
\hline \multirow[t]{2}{*}{$48 \mathrm{~h}$} & Control & $80.3 \pm 31.6$ & $4.9 \pm 1.1$ & $7.8 \pm 2.1$ & $101.2 \pm 26.5$ & $796.1 \pm 230.5$ & $3.0 \pm 0.5$ \\
\hline & Aerial & $53.4 \pm 10.6^{a}$ & $4.2 \pm 0.7$ & $6.5 \pm 1.9$ & $104.1 \pm 33.0$ & $903.6 \pm 202.6$ & $2.8 \pm 0.6$ \\
\hline
\end{tabular}

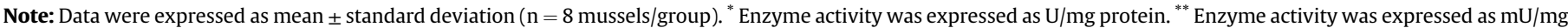
protein. ${ }^{* * *}$ Lipid peroxidation (MDA) was expressed as nmol/g tissue. a Significant difference $(\mathrm{p}<0.05)$ compared to the control of the same period.

Table 2

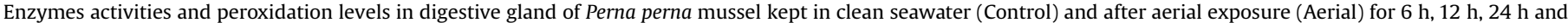
$48 \mathrm{~h}$.

\begin{tabular}{|c|c|c|c|c|c|c|c|}
\hline Time & Group & SOD $^{*}$ & CAT $^{*}$ & $\mathrm{GPx}^{* *}$ & $\mathrm{GR}^{* *}$ & $\mathrm{GST}^{* *}$ & $\mathrm{MDA}^{* * *}$ \\
\hline \multirow[t]{2}{*}{$6 \mathrm{~h}$} & Control & $301.5 \pm 119.7$ & $33.0 \pm 33.0$ & $32.1 \pm 12.3$ & $86.7 \pm 44.0$ & $1263.6 \pm 185.5$ & $1.4 \pm 0.1$ \\
\hline & Aerial & $306.7 \pm 180.2$ & $24.8 \pm 24.2$ & $22.8 \pm 11.1$ & $92.1 \pm 77.5$ & $749.9 \pm 185.5$ & $1.1 \pm 0.2^{\mathrm{a}}$ \\
\hline \multirow[t]{2}{*}{$12 \mathrm{~h}$} & Control & $280.8 \pm 131.9$ & $17.7 \pm 3.6$ & $10.0 \pm 1.1$ & $101.6 \pm 20.4$ & $170.6 \pm 58.2$ & $4.3 \pm 2.3$ \\
\hline & Aerial & $93.6 \pm 14.4^{\mathrm{a}}$ & $14.6 \pm 4.0$ & $8.4 \pm 2.5$ & $62.0 \pm 22.9^{\mathrm{a}}$ & $183.5 \pm 55.0$ & $5.2 \pm 1.4$ \\
\hline \multirow[t]{2}{*}{$24 \mathrm{~h}$} & Control & $141.2 \pm 45.5$ & $12.6 \pm 4.6$ & $9.1 \pm 2.5$ & $103.3 \pm 17.9$ & $162.5 \pm 46.5$ & $5.2 \pm 2.0$ \\
\hline & Aerial & $150.5 \pm 35.4$ & $15.8 \pm 1.3$ & $10.1 \pm 3.3$ & $119.6 \pm 29.1$ & $149.9 \pm 43.4$ & $5.6 \pm 2.0$ \\
\hline \multirow[t]{2}{*}{$48 \mathrm{~h}$} & Control & $73.8 \pm 6.5$ & $14.7 \pm 3.4$ & $8.7 \pm 2.0$ & $38.8 \pm 23.1$ & $190.3 \pm 78.9$ & $5.3 \pm 1.3$ \\
\hline & Aerial & $69.0 \pm 18.6$ & $16.7 \pm 2.3$ & $11.8 \pm 2.6^{\mathrm{a}}$ & $74.5 \pm 13.3^{a}$ & $148.8 \pm 33.0$ & $8.0 \pm 3.7$ \\
\hline
\end{tabular}

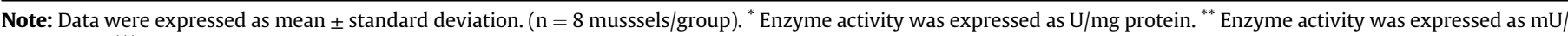
mg protein. ${ }^{* * *}$ Lipid peroxidation $(\mathrm{MDA})$ was expressed as nmol/g tissue. ${ }^{\text {a }}$ Significant difference $(\mathrm{p}<0.05)$ compared to the control group of the same period.

(A)

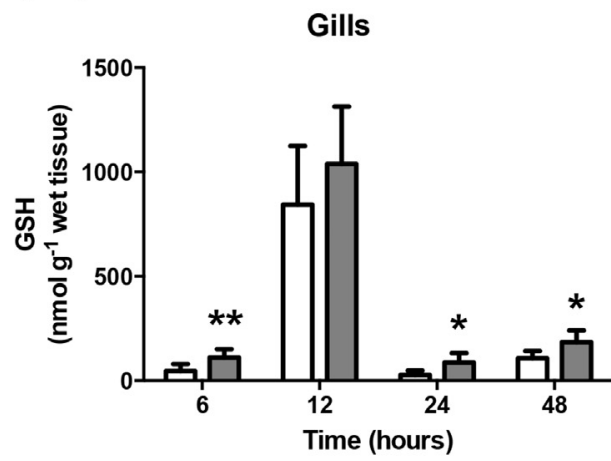

(B)

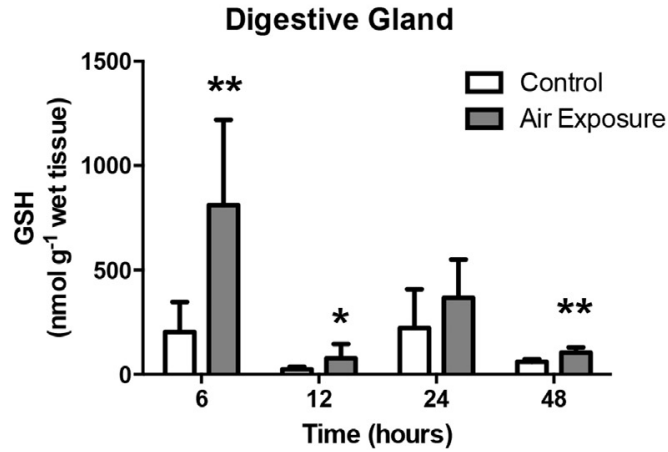

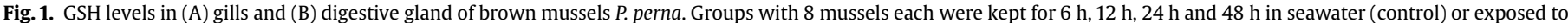
the air (aerial). Data are shown as average \pm standard deviation. ${ }^{*} \mathrm{p}<0.05$ and ${ }^{* *} \mathrm{p}<0.01$.

activities or mRNA levels in the gills of clams (Philipp et al., 2012), as well as in the hepatopancreas of sea snail (Pannunzio and Storey, 1998). However, whether the observed modulation of SOD and CAT in mussels $P$. perna plays a role in mediating ROS levels during hypoxia remains to be further studied, since other antioxidant systems were amplified and prolonged hypoxia did not lead to an accumulation of lipid peroxidation end products.

It should be commented that antioxidant enzymes in the control groups presented significant alterations within exposure time. In general, the antioxidant enzymes were higher at the initial periods of the experiment, and then decreased along the other times of exposures, especially SOD and GPx in the gills and SOD, CAT, GPX and GST in the liver. Such variations could be due to natural variations of these parameters in mussels as a consequence of circadian rhythms of the animals, or could be also a reflection of manipulation stress during the first periods of the experiments. However, these hypotheses remains to be further investigated. Nevertheless, as the same pattern of enzymatic activities was also followed by the air-exposed groups, we consider that these temporal variations do not represent an issue for attributing the hypoxia effects observed on antioxidant defenses.

One of the most prominent effects of hypoxia on mussels P. perna was the increase in GSH levels, which was observed in both gills and digestive gland, as early as $6 \mathrm{~h}$, and stayed elevated up to $48 \mathrm{~h}$. Increased GSH synthesis is a classic adaptive response to counteract oxidative stress (Lu, 2013), as consumption of GSH by conjugation, oxidation, export to the extracellular milieu, or degradation can be compensated by GSH synthesis (van derOost et al., 2003). Induction of glutamate-cysteine ligase (GCL), the rate-limiting enzyme in GSH synthesis, is a classical marker of activation of the Nrf2 pathway (Satoh et al., 2014). Such activation has been reported in vitro as essential for cell survival during hypoxic conditions (Kolamunne et al., 2013). It is possible that the increase in GSH levels detected in this study could be a 
(A)

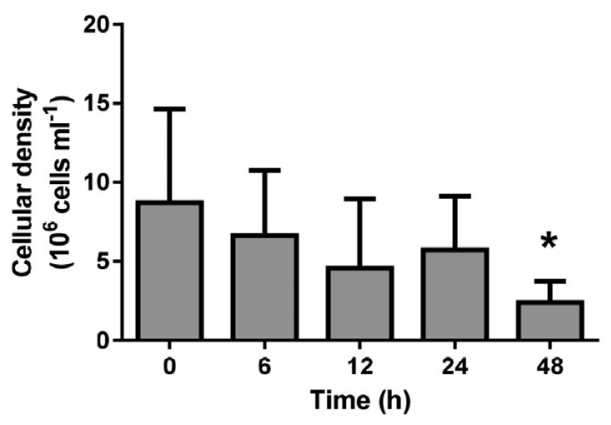

(C)

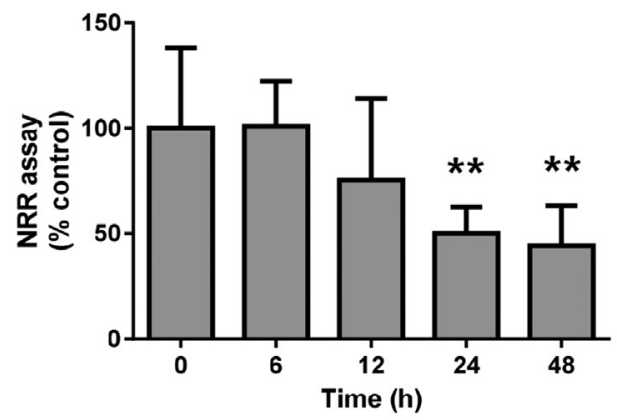

(B)

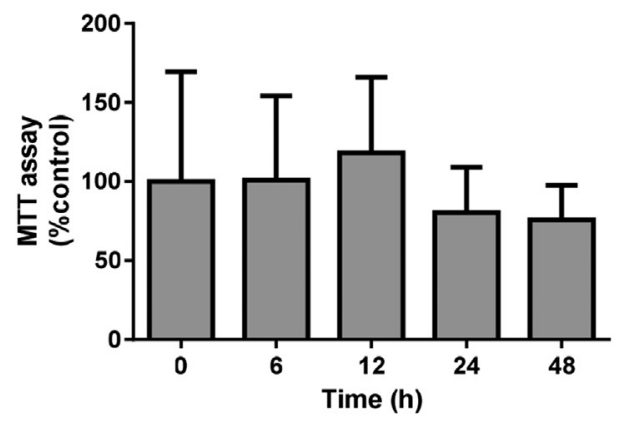

(D)

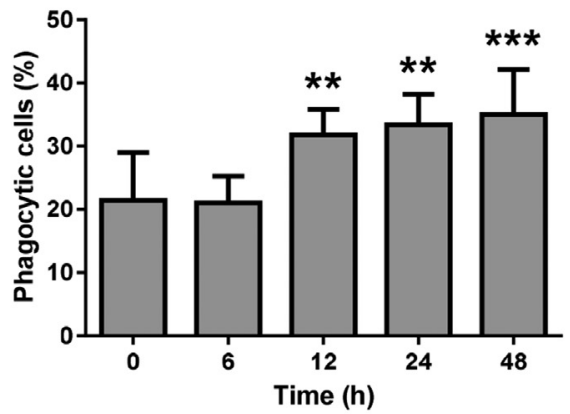

(E)

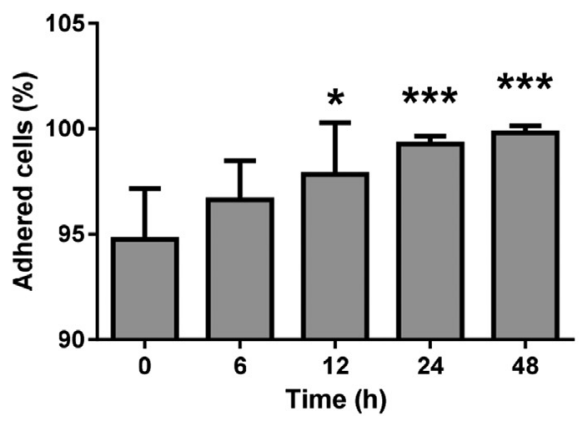

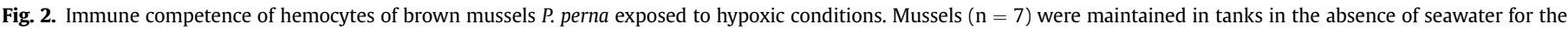

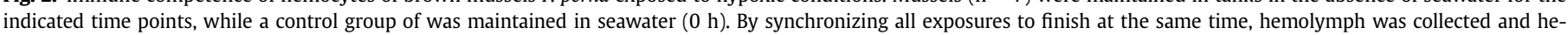

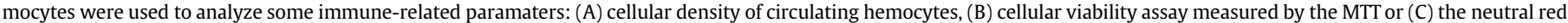

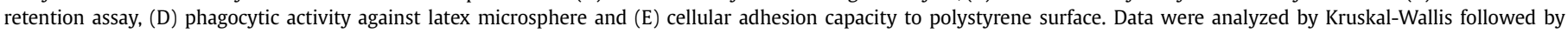

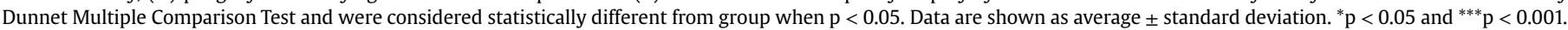

consequence of GCL induction. For instance, it has been shown in oysters Crassostrea gigas that in order to sustain the GSH-mediated biotransformation of electrophilic compounds, there is a fast upregulation of GCL transcripts leading to a rapid increase in GSH synthesis (Trevisan et al., 2016). In the present work, the increase in GSH levels in both the gills and the digestive gland could be an indicative of an early and primary protective response, preparing the tissue to prevent the expected oxidative damage during the reperfusion of oxygen into the cells (Pannunzio and Storey, 1998; Hermes-Lima et al., 2015; Moreira et al., 2016). Increased GSH levels may also be involved with the detoxification of pro-oxidants that can be accumulated during the period of hypoxia, as proposed by Pannunzio and Storey (1998).

The enzymes GR and GPx, which are related to the GSH metabolism, were affected in the digestive gland by hypoxia. Though GR had decreased activity after $12 \mathrm{~h}$, both enzymes increased their activities after $48 \mathrm{~h}$ of aerial exposure. Such upregulation coupled with higher GSH levels can increase the rate of peroxide elimination (Lubos et al., 2010). In vivo studies show that GR and GSH are important molecules for the detoxification of peroxides via GPX in P. perna, resulting in higher survival rates (Trevisan et al., 2014). This response can be interpreted as another protective mechanism triggered by hypoxia and as an anticipatory response to the oxidative stress induced in the reperfusion period (Pannunzio and Storey, 1998; Hermes-Lima et al., 2015; Moreira et al., 2016).

Except for the GSH levels, the temporal response of the antioxidant system was considerably variable, especially when the different tissues are taken into account. These two tissues are commonly associated in bivalves as main sites of biotransformation and detoxification of toxic compounds and the disparity in the antioxidant response between the two tissues is difficult to explain. It is known that in bivalves these tissues can exhibit different metabolic responses to hypoxia. For example, during aerobic conditions, both tissues use the tricarboxylic acid (TCA) cycle as the 
main oxidative pathway, while during anoxia the TCA cycle is markedly decreased in the digestive gland but remains partially operant in the gill (Chaplin and Loxton, 1976). Moreover, gills, due to the direct contact with the seawater and outer environment, are one of the first tissues to experience hypoxic conditions, quickly decreasing mitochondrial respiratory rate and proton leak, and increasing the efficiency of aerobic energy production (Sussarellu et al., 2013). In addition, due to the gapping behavior of $P$. perna when exposed to air, such opening/closure of the valves allows quick oxygen uptake (Nicastro et al., 2010), initially increasing oxygen concentrations in tissues such as gills and mantle. Therefore, it is expected that during air exposure in mussels $P$. perna, the cellular metabolic state, the oxygen levels and as consequence, the respective antioxidant system responses can differ between tissues.

Although prolonged hypoxia did not induce the accumulation of lipid peroxidation end products, it was clear that prolonged hypoxia can be stressful to these organisms based on negative effects on their immune competence. Decreased number of circulating cells in the hemolymph were detected after $48 \mathrm{~h}$ of air exposure. This same event was already detected in the shrimp Litopeneaus vannamei after 6 and 12 h of hypoxia (Wei et al., 2016), and in the mussel Mytilus coruscus (Sui et al., 2016). Lower hemocyte availability in the hemolymph can be a consequence of different outcomes caused by hypoxia, such as impaired proliferation, increased apoptosis/necrosis rate, as well as infiltration of hemocytes in other tissues (Mydlarz et al., 2006). As a lower cellular viability (estimated by the NRR assay) was also detected in hemocytes of mussels after prolonged exposure to hypoxia, it could be speculated that the decreased number of circulating hemocytes is probably due to cell death, which can be considered as a classic sign of poor bivalve health (Mydlarz et al., 2006). Moreover, loss of lysosomal membrane stability (determined by the NRR assay), already reported bivalves during different toxic conditions (Trevisan et al., 2012; Okoro et al., 2015; Parolini et al., 2014), may lead to loss of cellular function directly affecting the bivalve immune capacity. The increased phagocytic rate and cellular adhesion capacity after prolonged hypoxic conditions may indicate that these hemocytes are activated or immune stimulated. Sui et al. (2016) demonstrated that hypoxic conditions may account for increased ROS production in hemocytes of M. coruscus after $72 \mathrm{~h}$ of hypoxia, which could be also related to the increased phagocytic activity observed in our study. Moreover, although Wang et al. (2011) did not observe any change in phagocytic activity in the mussel Perna viridis along $48 \mathrm{~h}$ of hypoxia, it was increased after $96 \mathrm{~h}$ of hypoxia. Taken together, these data suggest that hypoxia can have a negative effect on the immune system of brown mussels, decreasing the availability of circulating viable hemocytes and causing modulation of their immune responses. Such conditions may have serious effects on their susceptibility to pathogens infections, as already suggested with crabs (Holman et al., 2004) and lobsters (Henroth et al., 2015) with impaired pathogen clearance due to continuous hypoxic conditions.

In summary, aerial exposure in brown mussels was characterized as a demanding condition to mussels $P$. perna, but mostly during prolonged exposures ( $24 \mathrm{~h}$ or more). Signs of antioxidant response were detected, with fast and consistent upregulation of glutathione levels in gills and digestive gland, as well as modulation of key antioxidant enzymes at least after $12 \mathrm{~h}$ of exposure, including increased GR and GPx activities after $48 \mathrm{~h}$ of aerial exposure. It is not clear how oxidative stress may play a role on hypoxia under such conditions as no accumulative lipid peroxidation damage was detected in such tissues. Even though, hemolymph cells were very sensitive to hypoxia, with limited availability of circulating cells and plausible uncoordinated cellular functions. $P$. perna should face hypoxic conditions on a very regular basis due to the tidal environment where it inhabits. Therefore, the fact that short-term exposure to hypoxia presented no major effects reinforces the idea that mussels are adapted to these conditions. On the other hand, prolonged hypoxia causes marked effects on the antioxidant and immune systems, suggesting it is toxic to bivalves, what could be an issue with the increasing worldwide occurrence of hypoxic conditions in coastal areas.

\section{Authors contributions}

L.N. planned and implemented the study, performed the experimental procedures, measured enzymes activity and lipid peroxidation, wrote the manuscript; D.F.M., R.T. planned and implemented the study, performed experimental procedures and assayed immune competence of hemocytes, wrote the manuscript; D.G. helped measuring enzymes activity and performed GSH quantification; D.S.A. contributed to experimental procedures; A.L.D., E.A.A. planned and implemented the study, wrote the manuscript.

\section{Acknowledgments}

We would like to thank "Fundação de Amparo a Pesquisa do Estado de São Paulo - FAPESP" for supporting our research (2010/ 20365-5). E.A.A. and A.L.D. are researcher fellows of Conselho Nacional de Desenvolvimento Científico e Tecnológico - CNPq". We are grateful to Dr. Nishad Jayasundara for proofreading the manuscript.

\section{References}

Abele, D., Philipp, E., Gonzalez, P.M., Puntarulo, S., 2007. Marine invertebrate mitochondria and oxidative stress. Front. Biosci. 12, 933-946.

Abele, D., Grosspietsch, H., Pörtner, H.O., 1998. Temporal fluctuations and spatial gradients of environmental $\mathrm{PO}_{2}$, temperature, $\mathrm{H}_{2} \mathrm{O}_{2}$ and $\mathrm{H}_{2} \mathrm{~S}$ in its intertidal habitat trigger enzymatic antioxidant protection in the capitellid worm Heteromastus filiformis. Mar. Ecol. Prog. Ser. 163, 179-191.

Almeida, E.A., Bainy, A.C.D., Dafre, A.L., Gomes, O.F., Medeiros, M.H.G., Di Mascio, P. 2005. Oxidative stress in digestive gland and gill of the brown mussel Perna perna exposed to air and re-submersed. J. Exp. Mar. Biol. Ecol. 318, 21-30.

Berry, P.F., Schleyer, M.H., 1983. The brown mussel Perna perna on the Natal coast South Africa: utilization of available food and energy budget. Mar. Ecol. Prog. Ser. 13, 201-210.

Beutler, E., 1975. Red Cell Metabolism: a Manual of Biochemical Methods. Grune \& Stratton, New York.

Bradford, M.M., 1976. A rapid and sensitive method for the quantitation of microgram quantities of protein utilizing the principle of protein-dye binding. Anal. Biochem. 72, 248-254.

Carlberg, I., Mannervik, B., 1985. Glutathione-reductase. Methods Enzymol. 113, 484-490.

Chandel, N.S., McClintock, D.S., Feliciano, C.E., Wood, T.M., Melendez, J.A., Rodriguez, A.M., Schumacker, P.T., 2000. Reactive oxygen species generated at mitochondrial complex III stabilize hypoxia-inducible factor- $1 \alpha$ during hypoxia. J. Biol. Chem. 275, 25130-25138.

Chaplin, A.E., Loxton, J., 1976. Tissue Differences in the response of the mussel Mytilus edulis to experimentally induced anaerobiosis. Biochem. Soc. Trans. 4, 437-441.

Cheng, W.T., Hsiao, I.S., Hsu, C.H., Chen, J.C., 2004a. Change in water temperature on the immune response of Taiwan abalone Haliotis diversicolor supertexta and its susceptibility to Vibrio parahaemolyticus. Fish. Shellfish Immunol. 17, 235-243.

Cheng, W.T., Li, C.H., Chen, J.C., 2004b. Effect of dissolved oxygen on the immune response of Haliotis diversicolor supertexta and its susceptibility to Vibrio parahaemolyticus. Aquaculture 232, 103-115.

D'Autreaux, B., Toledano, M.B., 2007. ROS as signalling molecules: mechanisms that generate specificity in ROS homeostasis. Nat. Rev. Mol. Cell. Bio 8, 813-824.

David, E., Tanguy, A., Pichavant, K., Moraga, D., 2005. Response of the Pacific oyster Crassostrea gigas to hypoxia exposure under experimental conditions. FEBS J. 272, 5635-5652.

Diaz, R.J., Rosenberg, R., 2008. Spreading dead zones and consequences for marine ecosystems. Sci. 321, 926-929.

Ferreira, M., Alencastro, A., Hermes-Lima, M., 2003. Role of antioxidant defenses during estivation and anoxia exposure in the freshwater snail Biomphalaria tenagophila (Orbigny, 1835). Can. J. Zool. 81, 1239-1248.

Fisher, W.S., Auffret, M., Balouet, G., 1987. Response of European flat oyster (Ostrea edulis) hemocytes to acute salinity and temperature changes. Aquaculture 67, 
$179-190$

Garbarino, V.R., Orr, M.E., Rodriguez, K.A., Buffenstein, R., 2015. Mechanisms of oxidative stress resistance in the brain: lessons learned from hypoxia tolerant extremophilic vertebrates. Arch. Biochem. Biophys. 576, 8-16.

Giannetto, A., Maisano, M., Cappello, T., Oliva, S., Parrino, V., Natalotto, A., De Marco, G., Barberi, C., Romeo, O., Mauceri, A., Fasulo, S., 2015. Hypoxia-inducible factor $\alpha$ and Hif-prolyl hydroxylase characterization and gene expression in short-time air-exposed Mytilus galloprovincialis. Mar. Biotechnol. 17, 768-781.

Gorr, T.A., Wichmann, D., Hu, J., Hermes-Lina, M., Welker, A.F., Terwilliger, N., Wren, J.F., Viney, M., Morris, S., Nilson, G.E., Deten, A., Soliz, J., Gassmann, M. 2010. Hypoxia tolerance in animals: biology and application. Physiol. Biochem. Zool. 83, 733-752.

Hermes-Lima, M., Zenteno-Savin, T., 2002. Animal response to drastic changes in oxygen availability and physiological oxidative stress. Comp. Biochem. Physiol. C Toxicol. Pharmacol. 133, 537-556.

Hermes-Lima, M., Moreira, D.C., Rivera-Ingraham, G.A., Giraud-Billoud, M., GenaroMattos, T.C., Campos, E.G., 2015. Preparation for oxidative stress under hypoxia and metabolic depression: revisiting the proposal two decades later. Free Radic. Biol. Med. 89, 1122-1143.

Henroth, B., Krang, A.S., Baden, S., 2015. Bacteriostatic suppression in Norway lobster (Nephrops norvegicus) exposed to manganese or hypoxia under pressure of ocean acidification. Aquat. Toxicol. 159, 217-224.

Holman, J.D., Burnett, K.G., Burnett, L.E., 2004. Effects of hypercapnic hypoxia on the clearance of Vibrio campbellii in the Atlantic blue crab. Callinectes sapidus Rathbun. Biol. Bull. 206, 188-196.

Johnson, P.T., Chase, J.M., Dosch, K.L., Hartson, R.B., Gross, J.A., Larson, D.J., Sutherland, D.R., Carpenter, S.R., 2007. Aquatic eutrophication promotes pathogenic infection in amphibians. Proc. Natl. Acad. Sci. U. S. A. 104, 15781-15786.

Keen, J.H., Habig, W.H., Jakoby, W.B., 1976. Mechanism for several activities of the gluthatione S-transferases. J. Biol. Chem. 251, 6183-6188.

Kolamunne, R.T., Dias, I.H.K., Vernallis, A.B., Grant, M.M., Griffiths, H.R., 2013. Nrf2 activation supports cell survival during hypoxia and hypoxia/reoxygenation in cardiomyoblasts; the roles of reactive oxygen and nitrogen species. Redox Biol. 1, 418-426.

Lu, S.C., 2013. Glutathione synthesis. BBA Gen. Subj. 1830, 3143-3153.

Lubos, E., Loscalzo, J., Handy, D.E., 2010. Glutathione peroxidase-1 in health and disease: from molecular mechanisms to therapeutic opportunities. Antioxid. Redox Signal 15, 1957-1997.

McCord, J.M., Fridovich, I., 1969. Superoxide dismutase: an enzymatic function for erythrocuprein (hemocuprein). J. Biol. Chem. 244, 6049-6055.

Monari, M., Matozzo, V., Foschi, J., Cattani, O., Serrazanetti, G.P., Marin, M.G., 2007 Effects of high temperature on functional responses of haemocytes in the clam Chamelea gallina. Fish. Shellfish Immunol. 22, 98-114.

Moreira, D.C., Venancio, L.P., Sabino, M.A., Hermes-Lima, M., 2016. How widesprea is preparation for oxidative stress in the animal kingdom? Comp. Biochem. Physiol. A 200, 64-78.

Murphy, M.P., 2009. How mitochondria produce reactive oxygen species. Biochem. J. 417, 1-13.

Mello, D.F., Arl, M., Trevisan, R., Dafre, A.L., 2015. How important are glutathione and thiol reductases to oyster hemocyte function? Fish. Shellfish Immunol. 46 $566-572$.

Mydlarz, L.D., Jones, L.E., Harvell, C.D., 2006. Innate immunity environmental drivers and disease ecology of marine and freshwater invertebrates. Annu. Rev. Ecol. Evol. Syst. 37, 251-288.

Nicastro, K.R., Zardi, G., McQuaid, C.D., Stephens, L., Radloff, S., Blatch, G.L., 2010. The role of gaping behaviour in habitat partitioning between coexisting intertidal mussels. BMC Ecol. 10, 17.

Nordberg, J., Arnér, E.S.J., 2001. Reactive oxygen species, antioxidants, and the mammalian thioredoxin system. Free Radic. Bio. Med. 31, 1287-1312.

Okoro, H.K., Snyman, R.G., Fatoki, O.S., Adekola, F.A., Ximba, B.J., Slabber, M.Y., 2015 Lysosomal membrane stability of the mussel, Mytilus galloprovincialis (L.), as a biomarker of tributyltin exposure. Bull. Environm. Contam. Toxicol. 94, 609-613.

Pampanin, D.M., Ballarin, L., Carotenuto, L., Marin, M.G., 2002. Air exposure and functionality of Chamelea gallina haemocytes: effects on haematocrit, adhesion, phagocytosis and enzyme contents. Comp. Biochem. Physiol. Part A 131, 605-614.

Pannunzio, T.M., Storey, K.B., 1998. Antioxidant defenses and lipid peroxidation during anoxia stress and aerobic recovery in the marine gastropod Littorina littorea. J. Exp. Mar. Biol. Ecol. 221, 277-292.

Parolini, M., Magni, S., Binelli, A., 2014. Environmental concentrations of 3,4methylenedioxymethamphetamine (MDMA)-induced cellular stress and modulated antioxidant enzyme activity in the zebra mussel. Environm. Sci. Pollut. Res. Int. 21, 11099-11106.

Philipp, E.E.R., Wessels, W., Gruber, H., Strahl, J., Wagner, A.E., Ernst, I.M.A., Rimbach, G., Kraemer, L., Schreiber, S., Abele, D., Rosenstiel, P., 2012. Gene expression and physiological changes of different populations of the long-lived bivalve Arctica islandica under low oxygen conditions. PLoS One 7, e44621.

Rivera-Ingraham, G., Rocchetta, I., Meyer, S., Abele, D., 2013. Oxygen radical formation in anoxic transgression and anoxia-reoxygenation: foe or phantom? Experiments with a hypoxia tolerant bivalve. Mar. Environm. Res, 92, 110-119.

Rodriguez-Ariza, A., Toribio, F., Lopez-Barea, J., 1994. Rapid determination of glutathione status in fish liver using high-performance liquid chromatography and electrochemical detection. J. Chromatogr. 656, 311-318.

Satoh, T., McKercher, S.R., Lipton, S.A., 2014. Reprint of: Nrf2/ARE-mediated antioxidant actions of pro-electrophilic drugs. Free Radic. Biol. Med. 66, 45-57.

Schrader, M., Fahimi, H.D., 2006. Peroxisomes and oxidative stress. Biochim. Biophys. Acta $1763,1755-1766$

Siddall, E.E., 1980. A clarification of the genus Perna (Mytilidae). Bull. Mar. Sci. 30, $858-870$

Sies, H., Koch, O.R., Martino, E., Boveris, A., 1979. Increased biliary glutathione disulfide release in chronically ethanol treated rats. FEBS Lett. 103, 287-290.

Sui, Y., Kong, H., Shang, Y., Huang, X., Wu, F., Hu, M., Lin, D., Lu, W., Wang, Y., 2016. Effects of short-term hypoxia and seawater acidification on hemocyte responses of the mussel Mytilus coruscus. Mar. Pollut. Bull. 15108 (1-2), 46-52.

Sussarellu, R., Fabioux, C., Le Moullac, G., Fleury, E., Moraga, D., 2010. Transcriptomic response of the Pacific oyster Crassostrea gigas to hypoxia. Mar. Genomics 3, $133-143$.

Sussarellu, R., Dudognon, T., Fabjoux, C., Soudant, P., Moraga, D., Kraffe, E., 2013. Rapid mitochondrial adjustments in response to short-term hypoxia and re=oxygenation in the Pacific oyster, Crassostrea gigas. J. Exp. Biol. 216, 1561-1569.

Trevisan, R., Arl, M., Sacchet, C.L., Engel, C.S., Danielli, N.M., Mello, D.F., Brocardo, P., Maris, A.F., Dafre, A.L., 2012. Antioxidant deficit in gills of Pacific oysters (Crassostrea gigas) exposed to chlorodinitrobenzene increases menadione toxicity. Aquat. Toxicol. 108, 85-93.

Trevisan, R., Mello, D.F., Uliano-Silva, M., Delapedra, G., Dafre, A.L., 2014. The biological importance of glutathione peroxidase end peroxiredoxin backup systems in bivalves during peroxide exposure. Mar. Environm. Res. 101, 81-90.

Trevisan, R., Mello, D.F., Delapedra, G., Silva, D.G., Arl, M., Danielli, N.M., Metian, M., Almeida, E.A., Dafre, A.L., 2016. Gills as a glutathione-dependent metabolic barrier in Pacific oysters Crassostrea gigas: absorption, metabolism and excretion of a model electrophile. Aquat. Toxicol. 173, 105-119.

van der Oost, R., Beyer, J., Vermeulen, N.F., 2003. Fish bioaccumulation and biomarkers in environmental risk assessment: a review. Environ. Toxicol. Pharmacol. 13, 57-149.

Wang, Y., Hu, M., Shin, P.K., Cheung, S.G., 2011. Immune responses to combined effect of hypoxia and high temperature in the green-lipped mussel Perna viridis. Mar. Pollut. Bull. 63, 201-208.

Wang, Y., Hu, M., Shin, P.K., Cheung, S.G., Shin, P.K.S., Lu, W., Li, J., 2012. Immune parameter changes of hemocytes in green-lipped mussel Perna viridis exposure to hypoxia and hyposalinity. Aquaculture 356-357, 22-29.

Wang, Y., Hu, M., Li, O., Li, J., Lin, D., Lu, W., 2014. Immune toxicity of TiO2 under hypoxia in the green-lipped mussel Perna viridis based on flow cytometric analysis of hemocyte parameters. Sci. Tot. Environ. 47-471, 791-799.

Wei, L., Li, Y., Qiu, L., Zhou, Q., Han, Q., Diao, X., 2016. Comparative studies of hemolymph physiology response and HIF-1 expression in different strains of Litopenaeus vannameiunder acute hypoxia. Chemosphere 153, 198-204.

Welker, A.F., Moreira, D.C., Campos, É.G., Hermes-Lima, M., 2013. Role of redox metabolism for adaptation of aquatic animals to drastic changes in oxygen availability. Comp. Biochem. Physiol. A 165 (4), 384-404.

Zardi, G.I., Nicastro, K.R., McQuaid, C.D., Castilho, R., Costa, J., Serrão, E.A., Pearson, G.A., 2015. Intraspecific genetic lineages of a marine mussel show behavioural divergence and spatial segregation over a tropical/subtropical biogeographic transition. BMC Evol. Biol. 15, 100. 